Journal of Social Sciences and Politics

Vol. 7 No. 2 April 2020

p-ISSN : 2252-4150

e-ISSN : 2716-3474

Tersedia online di http://ejurnal.stisipolcandradimuka.ac.id/index.php/JurnalPublisitas/

\title{
Analisis Kebijakan Program Pembinaan Anak Jalanan Oleh Dinas Sosial Di Ogan Iir
}

\author{
Khoirin $^{1}$, Heru Purnawan ${ }^{2}$, Dian Anggraini ${ }^{3}$ \\ ${ }^{1}$ Program Studi Ilmu Administrasi Negara, STISIPOL Candradimuka, Jl-Swadaya Palembang \\ ${ }^{2}$ Program Studi Ilmu Administrasi Negara, Universitas Prof. Dr. Hazairin, SH Bengkulu \\ ${ }^{3}$ Program Studi Ilmu Administrasi Negara, STIA Satyanegara Palembang \\ E-mail: khoirin@ $\underline{\text { stisipolcandradimuka.ac.id }}{ }^{1}, \underline{\text { shane.purnawan @ gmail.com }}^{2}, \underline{\text { bundafira81@ @mail.com }}^{3}$
}

\begin{abstract}
ABSTRAK
Penelitian ini dilaksanakan di Kantor Dinas Sosial Kabupaten Ogan Ilir. Peneliti mengumpulkan data dengan observasi, dokumentasi, dan wawancara terhadap informan yang terpilih terkait pelaksanaan Program Pembinaan Anak Jalanan oleh Dinas Sosial Kabupaten Ogan Ilir. Rancangan penelitian yang digunakan dalam penelitian ini adalah penelitian yang bersifat deskriptif kualitatif dengan mengandalkan data empiris dan didukung data kualitatif. Hasil penelitian yang dilakukan menunjukan [1] Pelaksanaan Program Pembinaan Dinas Sosial Terhadap Anak Jalanan di Kota Indralaya pada dasarnya adalah memberikan bantuan dalam hal pembinaan menanggulangi masalah anak jalanan yang pada akhirnya diarahkan kedalam bentuk pendataan dan pembinaan psikis (konseling) akan pentingnya pendidikan serta memfasilitasi pertemuan dengan keluarganya. [2] Kualitas pembinaan anak jalanan selama ini masih rendah terkait kurangnya tindakan nyata dalam pelaksanaan program pembinaan anak jalanan. Dinas Sosial Kabupaten Ogan Ilir sudah berusaha semaksimal mungkin guna menekan angka pertumbuhan anak jalanan, dimana kendala utama yang dihadapi adalah kota indralaya sebagai daerah transit memungkinkan anak ataupun kaum apa saja dapat singgah di daerah ini. Hal ini tentu menyulitkan dalam hal pendataan, melanjutkan sekolah mereka bahkan membuka lowongan kerja untuk mereka dengan keterbatasan dana dimiliki.
\end{abstract}

Kata Kunci: Analisis Kebijakan, Program, Pembinaan Anak Jalanan

\section{ABSTRACT}

This research was conducted at the Office of Social Affairs of Ogan Ilir Regency which is relevant to the problems in this study. Researchers collected data by observation, documentation, and interviews with selected informants related to the implementation of the Street Children Development Program by the Ogan Ilir District Social Service. The research design used in this study is a qualitative descriptive study by relying on empirical data and supported by qualitative data. The results of the research conducted show [1] The implementation of the Social Service Development Program for Street Children in Indralaya City is basically providing assistance in terms of coaching overcoming the problems of street children which are ultimately directed into the form of data collection and psychological guidance (counseling) on the importance of education and facilitating meeting with his family. [2] The quality of coaching street children so far is still low due to the lack of concrete action in implementing the street children guidance program. But basically the Social Service of Ogan Ilir Regency has made every effort to reduce the growth rate of street children, where the main 
obstacle faced is that the Indralaya City as a transit area allows children or any kind of people to stop by in this area. This certainly makes it difficult in terms of data collection, continuing their schooling and even opening job vacancies for those with limited funds.

Keywords: Policy Analysis, Programs, Street Children Development

\section{PENDAHULUAN}

Pertumbuhan jumlah anak jalanan merupakan salah satu dampak negatif dalam pembangunan, khususnya pembangunan perkotaan seiring dengan pertumbuhan jumlah penduduk yang kian hari kian bertambah sehingga menimbulkan jumlah angka kriminalitas juga ikut bertambah. Keberhasilan percepatan pembangunan di wilayah perkotaan dan sebaliknya keterlambatan pembangunan di wilayah pedesaan mengundang arus migrasi desa ke kota yang antara lain mengakibatkan jumlah penduduk kian melonjak.

Terbitnya Peraturan Daerah (Perda) Kabupaten Ogan Ilir Nomor 3 Tahun 2012 Tentang Penyelenggaraan Kesejahteraan Sosial pada Pasal 12 ayat 1 bahwa Sasaran pelayanan kesejahteraan sosial penyandang masalah korban tindak kekerasan, eksploitasi dan diskriminasi meliputi : anak jalanan, pekerja anak, dan wanita. Dalam melaksanakan Perda tersebut Pemerintah Daerah Kabupaten Ogan Ilir melalui Kepala Daerah menunjuk Satuan Kerja Perangkat Daerah (SKPD) terkait dalam hal ini Dinas Sosial Kabupaten Ogan Ilir sebagai instansi pemerintah yang mempunyai wewenang untuk melarang anak jalanan baik yang dilakukan secara perorangan, kelompok dan atau disuruh orang lain untuk meminta-minta di jalanan umum atau simpang jalan yang dapat mengganggu ketertiban umum.
Perhatian terhadap nasib anak jalanan tampaknya belum begitu besar karena mereka adalah saudara kita, mereka juga adalah amanah Tuhan yang harus dilindungi dijamin hak-haknya, sehingga tumbuh kembang menjadi manusia dewasa yang bermanfaat, beradab dan bermasa depan cerah. Anak yang menghabiskan sebagian besar waktunya di jalanan menganggap bahwa mereka lebih baik bekerja dan mencari uang untuk jajan dari pada pergi ke sekolah karena malas berfikir. Mereka bisa mendapatkan kurang lebih Rp. 20.000 sampai Rp. 100.000 per hari dari bekerja di jalanan. Mereka merasa betah berada di jalanan. Anak-anak jalanan menjadi malas jika diajak ke habitat normal seperti anak seusia mereka pada umumnya (Huraerah, 2006:31).

Melihat berbagai kondisi fenomena yang dialami oleh anak jalanan, Pemerintah Daerah Kabupaten Ogan Ilir melalui Dinas Sosial Kabupaten Ogan Ilir mempunyai Program Pembinaan Anak Jalanan sebagai upaya dari pelaksanaan Peraturan Daerah (Perda) Kabupaten Ogan Ilir Nomor 3 Tahun 2012 Tentang Penyelenggaraan Kesejahteraan Sosial, dimana dengan program yang realistis ini akan tercipta kebijakan utama untuk mengentaskan masalah anak jalanan.

Namun, pada kenyataannya pelaksanaan program pembinaan anak jalanan di Kabupaten Ogan Ilir selama ini belum berjalan efektif, dimana masih 
banyaknya aktivitas anak-anak jalanan di Kota Indralaya Kabupaten Ogan Ilir yang beraneka ragam, diantaranya sebagai pengamen, anak punk, pedagang rokok, tukang semir sepatu, dan lain sebagainya. Mereka terutama beroperasi di tempattempat keramaian atau umumnya seperti di perempatan jalan, pasar, terminal serta lapangan bola yang mengijinkan mereka masuk untuk beroperasi seperti meminta uang dan mengamen.

Pembinaan yang diberikan kepada anak jalanan merupakan hal penting yang juga harus diperhatikan oleh Dinas Sosial Kabupaten Ogan Ilir. Selama ini pembinaan anak jalanan hanya sebatas pada saat terjaring razia, anak jalanan di Kota Indralaya hanyalah sebatas pendataan, diarahkan mengenai sosialisasi tentang dampak buruk anak jalanan yang untuk selanjutnya dikembalikan kepada alamat asalnya. Sehingga tidak memberikan efek jera serta dirasa kurangnya tindakan nyata dalam upaya pelaksanaan Program Pembinaan Dinas Sosial Terhadap Anak Jalanan di Kota Indralaya Kabupaten Ogan Ilir seperti melanjutkan sekolah bagi anak jalanan yang putus sekolah maupun menciptakan lapangan pekerjaan terhadap anak jalanan bila memang pekerjaan yang dilakukan sesuai dengan usia anak dan tidak terlalu membahayakan keselamatan jiwanya serta masih mendapatkan kesempatan untuk sekolah dan bermain maka tidak akan berpengaruh terhadap perkembangan anak.

Berdasarkan uraian yang telah dipaparkan pada latar belakang, penulis sangat tertarik untuk meneliti dan mengkaji lebih lanjut. Berdasarkan permasalahan yang diajukan oleh peneliti, maka penelitian ini bertujuan untuk, Menganalisa kebijakan program pembinaan anak jalanan oleh Dinas Sosial Kabupaten Ogan Ilir dan Mendeskripsikan faktor-faktor yang menjadi penghambat dalam kebijakan program pembinaan anak jalanan oleh Dinas Sosial Kabupaten Ogan Ilir.

\section{TINJAUAN PUSTAKA}

Wiliiam N. Dunn menyebut istilah kebijakan publik dalam bukunya yang berjudul Analisis Kebijakan Publik. Kebijakan Publik (Public Policy) adalah pola ketergantungan yang kompleks dari pilihan-pilihan kolektif yang saling bergantung, termasuk keputusankeputusan untuk tidak bertindak, yang dibuat oleh badan atau kantor pemerintah (Dunn, 2003:132).

Menganalisis suatu program atau kebijakan publik diperlukan adanya suatu kriteria untuk mengukur keberhasilan program atau kebijakan publik tersebut. Mengenai kinerja kebijakan dalam menghasilkan informasi terdapat kriteria analisis sebagai berikut:

Tabel 1. Kriteria Analisis

\begin{tabular}{ll}
\hline \multicolumn{1}{c}{ Tipe Kriteria } & \multicolumn{1}{c}{ Pertanyaan } \\
\hline Efektifitas & $\begin{array}{l}\text { Apakah hasil yang diinginkan telah } \\
\text { dicapai ? }\end{array}$ \\
\hline Efisiensi & $\begin{array}{l}\text { Seberapa banyak usaha diperlukan untuk } \\
\text { mencapai hasil yang diinginkan? }\end{array}$ \\
\hline Kecukupan & $\begin{array}{l}\text { Seberapa jauh pencapaian hasil yang } \\
\text { diinginkan memecahkan masalah? }\end{array}$ \\
\hline Perataan & $\begin{array}{l}\text { Apakah biaya dan manfaat } \\
\text { didistribusikan dengan merata kepada } \\
\text { kelompok-kelompok tertentu? }\end{array}$ \\
\hline Responsivitas & $\begin{array}{l}\text { Apakah hasil kebijakan memuaskan } \\
\text { kebutuhan, preferensi atau nilai } \\
\text { kelompok-kelompok tertentu? }\end{array}$ \\
\hline
\end{tabular}

Sumber: Dunn, 2003:610 
Suatu keberhasilan kebijakan dapat dilihat melalui tanggapan masyarakat yang menanggapi pelaksanaan setelah terlebih dahulu memprediksi pengaruh yang akan terjadi jika suatu kebijakan akan dilaksanakan, juga tanggapan masyarakat setelah dampak kebijakan sudah mulai dapat dirasakan dalam bentuk yang positif berupa dukungan ataupun wujud yang negatif berupa penolakan. Dunn pun mengemukakan bahwa Kriteria responsivitas adalah penting karena analisis yang dapat memuaskan semua kriteria lainnya (efektivitas, efisiensi, kecukupan, kesamaan) masih gagal jika belum menanggapi kebutuhan aktual dari kelompok yang semestinya diuntungkan dari adanya suatu kebijakan (Dunn, 2003:437).

Dalam mengatasi masalah yang dihadapai oleh anak jalanan tersebut, merupakan tugas sebagaimana yang diembangkan oleh pemerintah tentang pembinaan dan kesejahteraan anak dalam menjamin pertumbuhan dan perkembangannya dengan wajar baik jasmani dan rohani maupun sosialnya. Pembinan yang harus dilakukan bervariasi dimana melalui proses pendidikan, pembinaan mental, dan keagamaan yang berkualitas dengan segala aspek.

Dari batas pengertian tersebut Huraerah (2006) mengemukakan bahwa ciri-ciri anak jalanana yaitu:

a. Anak (laki-laki/perempuan) usia 7-21 tahun, melakukan kegiatan tidak menentu, dan membahayakan dirinya sendiri di tempat-tempat umum (jalanan, pasar, tempat hiburan, dan terminal. b. Berpendidikan rendah (kebanyakan putus sekolah, dan sedikit sekali yang tamat SD).

c. Berasal dari keluarga yang tidak mampu.

d. Melakukan aktifasi ekonomi.

Menurut data yang telah penulis peroleh dari Dinas Sosial, ciri anak jalanan terbagi dalam dua kategori yaitu ciri fisik dan psikis. Ciri fisik anak jalanan adalah anak jalanan yang mempunyai warna kulit kusam, rambut kemerah-merahan, kebanyakan berbadan kurus, dan berpakaian kotor. Sedangkan ciri psikis adalah mereka mempunyai mobilitas yang tinggi terutama untuk mempunyai rasa penuh curiga, sangat sensitif, tidak berfikir panjang (berani menanggung resiko) dan mandiri (Dinas Sosial Kabupaten Ogan Ilir, 2017).

Dapat kita lihat bahwa seseorang dikatakan anak jalanan bilamana mempunyai indikasi sebagai berikut:

a. Usia di bawah 18 tahun

b. Orientasi hubungan dengan keluarganya adalah hubungan yang sekedarnya, tidak ada komunikasi yang rutin diantara mereka:

1) Ada yang sama sekali tidak berhubungan dengan keluarganya.

2) Masih ada hubungan sosial secara teratur

3) Masih aada kontak dengan keluarganya, namun tidak teratur

c. Orientasi waktu hanya memiliki orientasi waktu masa kini, mereka tidak memiliki orientasi waktu mendatang

d. Orientasi tempat tinggal 
e. Orientasi tempat berkumpul mereka adalah tempat-tempat yang kumuh, kotor, banyak makanan sisa, tempat berkumpulnya orang orang, misalkan pasar, terminal bus, perempatan jalan atau jalan raya.

f. Orientasi aktifitas pekerjaan kegeiatan atau aktivitas yang mereka kerjakan adalah aktivitasnya yang berorientasi pada kemudahan mendapatkan uang sekedarnya untuk menyambung hidup, seperti menyemir sepatu,mengamen, menjajakan koran, kuli angkuat, pemulung dan penghubung penjualan jasa.

Permasalah-permasalahan yang biasa di hadapi oleh anak jalanan seperti, konflik dengan kelompok lain atau teman dalam kelompok, di kejar-kejar aparat, korban eksploitasi sex, ditolak masyarakat, sering terlibat kriminalitas dan berpotensi menimbulkan kecelakaan lalu lintas.

Disamping itu, karakteristik atau sifat yang menonjol dari anak jalanan diantaranya adalah:

a. Kelihatan kumuh atau kotor, baik kotor tubuh maupun kotor pakaian.

b. Memandang orang lain, yang tidak hidup dijalanan sebagai oarang yang dapat dimintai uang.

c. Mandiri artinya anak-anak tidak terlalu menggantungkan hidup terutama dalam hal tempat tidur dan makan.

d. Mimik wajah yang selalu memelas, terutama ketika berhubungan dengan orang yang bukan dari jalanan. Anakanak tidak memiliki rasa takut untuk berinteraksi dan berbicara dengan siapapun selama di jalanan.

e. Malas untuk melakukan kegiatan anak "rumahan" misalnya jadwal tidur selalu tidak beraturan, mandi, mebersihkan badan, gosok gigi, menyisir rambut, mencuci pakaian dan menyimpan pakaian.

\section{METODE PENELITIAN}

\section{Jenis Penelitian}

Metode penelitian menggunakan metode penelitian kualitatif. Dalam penelitian ini wawancara mendalam (Dept interview) akan dilakukan dengan pihak pegawai di Kabupaten Ogan ilir, anak jalanan, dan masyarakat di Ogan Ilir.

\section{Variabel Penelitian}

Dalam penelitian ini penulis akan melakukan pembahasan pada satu variabel yaitu menganalisi Kebijakan Program Pembinaan Anak Jalanan oleh Dinas Sosial Kabupatern Ogan Ilir.

Dalam penelitian ini yang menjadi indikatornya, secara lebih rinci tertera pada Tabel 2.

Tabel 2. Variabel Penelitian

\begin{tabular}{lll}
\hline \multicolumn{1}{c}{ Variabel } & \multicolumn{1}{c}{ Dimensi } & \multicolumn{1}{c}{ Indikator } \\
\hline \multirow{2}{*}{$\begin{array}{l}\text { Analisis } \\
\text { Kebijakan }\end{array}$} & Efektifitas & $\begin{array}{l}\text { 1. Target } \\
\text { 2. Pencapaian Tujuan }\end{array}$ \\
\cline { 2 - 3 } $\begin{array}{l}\text { Pembinaan } \\
\text { Anak }\end{array}$ & Efisiensi & $\begin{array}{l}\text { 1. Sumber Daya Manusia } \\
\text { 2. Sumber Daya Finansial }\end{array}$ \\
\cline { 2 - 3 } & Kecukupan & $\begin{array}{l}\text { 1. Kebutuhan } \\
\text { 2.Permasalahan }\end{array}$ \\
\cline { 2 - 3 } & Perataan & $\begin{array}{l}\text { 1.Keadilan } \\
\text { 2.Sasaran Kebijakan }\end{array}$ \\
\cline { 2 - 3 } & & $\begin{array}{l}\text { 1.Tanggapan } \\
\text { Sasaran } \\
\end{array}$ \\
\cline { 2 - 3 } & Responsivitas & 2.Tanggapan Masyarakat \\
\hline
\end{tabular}

Sumber: Dun (2003:610) 


\section{Informan Penelitian}

Tabel 3. Informan Penelitian

\begin{tabular}{cll}
\hline No & \multicolumn{1}{c}{ Informan } & Jumlah \\
\hline 1 & $\begin{array}{l}\text { Kepala Dinas Sosial } \\
\text { Kabupaten Ogan Ilir }\end{array}$ & 1 orang \\
\hline 2 & $\begin{array}{l}\text { Sekretaris Dinas Sosial } \\
\text { Kabupaten Ogan Ilir }\end{array}$ & 1 orang \\
\hline 3 & $\begin{array}{l}\text { Kepala Bidang } \\
\text { Rehabilitasi dan } \\
\text { Pemberdayaan Sosial }\end{array}$ & 1 orang \\
\hline 4 & $\begin{array}{l}\text { Kasi Pelayanan Anak, } \\
\text { Keluarga, dan Lansia }\end{array}$ & 1 orang \\
\hline 5 & $\begin{array}{l}\text { Kasi Pemberdayaan } \\
\text { Sosial }\end{array}$ & 1 orang \\
\hline 6 & $\begin{array}{l}\text { Staf di Dinas Sosial } \\
\text { Kabupaten Ogan Ilir }\end{array}$ & 2 orang \\
\hline 7 & $\begin{array}{l}\text { Aparat Satpol PP di } \\
\text { Lingkungan Dinas Sosial }\end{array}$ & 1 orang \\
\hline Masyarakat Kota & 2 orang \\
\hline
\end{tabular}

Sumber: diolah Penulis

Teknik Pengumpulan Data pada penelitian ini adalah Observasi, Wawancara, Dokumentasi, dan Studi pustaka. Teknik Analisis Data yaitu, Pengumpulan Informasi: Pengumpulan informasi melalui wawancara terhadap key informan yang compatible terhadap penelitian kemudian observasi langsung ke lapangan untuk menunjang penelitian yang dilakukan agar mendapatkan sumber data yang diharapkan. Uji Confirmabilityi : Uji Confirmability, berarti menguji hasil penelitian yaitu kegiatan sekumpulan informasi dalam bentuk teks naratif, tabel dan bagan yang bertujuan mempertajam pemahaman penelitian.

\section{PEMBAHASAN}

Target yang ditetapkan oleh Dinas Sosial Kabupaten Ogan Ilir terkait pembinaan anak jalanan adalah dengan meningkatkan partisipasi masyarakat agar kiranya tidak terlalu "memanjakan" atau dalam artian jangan selalu memberikan uang kepada anak jalanan yang sering mereka temui di sekitar Kota Indralaya karena pada akhirnya target kebijakan Program Pembinaan Dinas Sosial Terhadap Anak Jalanan di Kota Indralaya oleh Dinas Sosial Kabupaten Ogan Ilir adalah sebagai wadah dalam memberikan pembinaan maksimal dalam meningkatkan kesejahteraan sosial kepada anak jalanan yang berada di Kota Indralaya

Tujuan dari pelaksanaan Program Pembinaan Dinas Sosial Terhadap Anak Jalanan di Kota Indralaya pada dasarnya adalah memberikan bantuan dalam menanggulangi masalah anak-anak berbasis di jalanan yang pada akhirnya diarahkan kedalam bentuk peningkatan kesejahteraan dan pengurangan anak jalanan di seputaran wilayah Kota Indralaya sebagai ibukota Kabupaten Ogan Ilir.

Tujuan yang baik jika tidak diiringi dengan kesungguhan aparatur dan juga dukungan masyarakat maka tujuan tersebut kemungkinan hanya akan menjadikan wacana saja dan tidak akan tercapai. Analoginya bahwa tujuan pelaksanaan pembinaan anak jalanan pada dasarnya adalah memberikan pembinaan maksimal dalam mengurangi angka anak jalanan dan memutus mata rantai anak jalanan di Kota Indralaya.

Sumber daya yang ada sudah cukup memadai, hanya tinggal bagaimana konsisten dan optimalisasi itu tidak hanya terjaga dalam waktu yang singkat saja, namun terwujud dan terlaksana hingga benar-benar tujuan Program Pembinaan Dinas Sosial Terhadap Anak Jalanan di Kota Indralaya tercapai dengan baik. 
Sumber daya manusia sangat berpengaruh besar terhadap tercapainya tujuan suatu program/kebijakan. Berkaitan denga hal tersebut telah adanya usaha yang dilakukan aparatur pemerintah daerah Kabupaten Ogan Ilir terkait Pelaksanaan Program Pembinaan Dinas Sosial Terhadap Anak Jalanan di Kota Indralaya pada Tahun 2017 sebagai bentuk tanggung jawabnya sebagai pelayan publik dalam mencapai tujuan yang telah direncanakan, walau ada halhal yang harus dibenahi seperti menjaga konsistensi terhadap tanggung jawab pekerjaan yang ada demi terwujudnya tujuan secara optimal dan dapat dirasakan masyarakat secara sepenuhnya.

Pendanaan Program Pembinaan Dinas Sosial Terhadap Anak Jalanan di Kota Indralaya didanai melalui APBN pada DIPA Direktorat Jaminan Kesejahteraan Sosial Direktorat Jendral Bantuan dan Jaminan Sosial Kementerian Sosial RI. Anggaran dana tersebut terdiri dari bantuan untuk pembinaan anak jalanan dan penunjang. Dalam manajemen pendanaan pelaksanaan pembinaan tertahap anak jalanan di Kota Indralaya telah berjalan dengan baik dan diharapkan penggunaan uang yang diperoleh dimanfaatkan untuk melakukan pembinaan secara berkala.

Sampai saat ini, Dinas Sosial memiliki sumber dana dari APBD. Itu sudah termasuk untuk patroli, selama pembinaan, maupun apabila kami harus memulangkan anak jalanan ke tempat tinggalnya maupun memasukan mereka ke sekolah. Dana yang diperoleh Dinas Sosial Kabupaten Ogan Ilir untuk melaksanakan kebijakan pembinaan anak jalanan pada dasaranya sudah mencukupi.
Tetapi dari tiga pernyataan yang penulis dapatkan dari hasil wawancara dengan narasumber dapat disimpulkan bahwa pihak Dinas Sosial Kabupaten Ogan Ilir masih menggangap bahwa dana yang diperoleh untuk melaksanakan pembinaan anak jalanan ini masih kurang.

Permasalahan anak jalanan hadir dikarenakan berbagai faktor disamping aspek ekonomi, keberadaan anak jalanan pada saat ini juga dipengaruhi oleh lingkungan keluarga yang tidak harmonis. Pertumbuhan jumlah anak jalanan merupakan salah satu dampak negatif dalam pembangunan, khususnya pembangunan perkotaan seiring dengan pertumbuhan jumlah penduduk yang kian bertambah sehingga menimbulkan jumlah angka kriminalitas juga ikut bertambah.

Pada tahapan pelaksanaan ini juga telah ditetapkan konsep pelaksanaan serta personel yang terlibat pada organisasinya, kemudian secara detail menetapkan jadwal, program, alokasi biaya, serta alokasi sumber daya yang digunakan agar kedepannya dapat disempurnakan.

Sasaran dari kebijakan pembinaan anak jalanan jelas tertuju khusus kepada anak jalanan yang mana tujuan akhirnya diharapkan adalah berkurang jumlah anak jalanan. Sasaran kegiatan tidak akan terlaksana tanpa adanya tindakantindakan yang berhubungan dengan tujuan dari pelaksanaan program/kegiatan. sasaran kegiatan dalam penyusunan perencanaan pembinaan anak jalanan telah terencana secara jelas, baik dimulai dari Patroli ke beberapa wilayah keramaian kota serta mekanismenya dalam pembinaan awal bagi anak jalanan. Kurangnya tindakan nyata dalam 
pelaksanaan Program Pembinaan Anak Jalanan oleh Dinas Sosial Kabupaten Ogan Ilir, seperti upaya melanjutkan sekolah bagi anak jalanan yang putus sekolah, dan mennciptakan lapangan pekerjaan terhadap anak jalanan, akan tetapi sikap pegawai dalam memberikan layanan dalam program penanganan anak jalanan itu sudah sesuai dengan aturan yang ada dalam artian sesuai dengan standar operasioanal prosedur dari Dinas Sosial, walaupun adanya ketidakpuasan dari sasaran kebijakan dalm hal ini anak jalanan.

Melihat pada Implementasi Program Pembinaan Dinas Sosial Terhadap Anak Jalanan di Kota Indralaya, tanggapan masyarakat terkait dari pelaksanaan kebijakan tersebut sudah berusaha memberikan pelayanan kepada masyarakat agar merasa nyaman. Uraian yang telah peneliti sampaikan diatas menjadikan suatu gambaran bahwa Pembinaan Dinas Sosial Terhadap Anak Jalanan sudah menunjukan usaha yang cukup baik dalam pelaksanaannya.

\section{KESIMPULAN DAN SARAN Kesimpulan}

Berdasarkan hasil penelitian disimpulkan, bahwa:

1. Pelaksanaan Program Pembinaan Dinas Sosial Terhadap Anak Jalanan di Kota Indralaya pada dasarnya sudah efektif, dimana dengan memberikan bantuan dalam hal pembinaan menanggulangi masalah anak jalanan yang pada akhirnya diarahkan kedalam bentuk pendataan dan pembinaan psikis (konseling) akan pentingnya pendidikan serta memfasilitasi pertemuan dengan keluarganya.

2. Kualitas pembinaan anak jalanan selama ini belum efektif terkait kurangnya tindakan nyata dalam pelaksanaan program pembinaan anak jalanan. Namun pada dasarnya Dinas Sosial Kabupaten Ogan Ilir sudah berusaha semaksimal mungkin guna menekan angka pertumbuhan anak jalanan, dimana kendala utama yang dihadapi adalah kota indralaya sebagai daerah transit memungkinkan anak ataupun kaum apa saja dapat singgah di daerah ini. Hal ini tentu menyulitkan dalam hal pendataan, melanjutkan sekolah mereka bahkan membuka lowongan kerja untuk mereka dengan keterbatasan dana dimiliki.

3. Sumber Daya terkait pelaksanaan Program Pembinaan Dinas Sosial Terhadap Anak Jalanan di Kota Indralaya sudah berjalan cukup efektif.

4. Pelaksanaan Program Pembinaan Dinas Sosial Terhadap Anak Jalanan di Kota Indralaya memberikan suatu pemahaman bahwa sudah ada upaya yang cukup baik untuk menciptakan dampak positif dalam kaitannya dengan lingkungan terhadap Program Pembinaan Dinas Sosial Terhadap Anak Jalanan di Kota Indralaya.

\section{Saran}

Perlunya peningkatan kualitas pembinaan yang tidak hanya dengan pembinaan psikis (konseling) tetapi dapat terpenuhinya pendidikan yang layak bagi anak jalanan yang putus sekolah dan membuka lapangan pekerjaan bagi anak jalanan. Bahwa untuk kedepannya 
diharapkan Dinas Sosial dalam menjalankan program perlu menambah sumber daya financial yang ada sehingga mampu memberikan layanan yang lebih efektif dan efisien.

Konsistensi dalam pelaksanaan program pembinaan dinas sosial terhadap anak jalanan agar lebih ditingkatkan. Sosialisasi mengenai arti pentingnya keberadaan pelaksanaan program pembinaan dinas sosial terhadap anak jalanan hendaknya rutin dilaksanakan.

\section{DAFTAR PUSTAKA}

[1] Peraturan Daerah Kabupaten Ogan Ilir Nomor 3 Tahun 2012 Tentang Penyelenggaraan Kesejahteraan Sosial.

[2] Huraerah, Abu, 2006. Kekerasan Terhadap, Anak: Fenomena Masalah Sosial Kritis di Indonesia. Bandung: Nuansa.
[3] Huraerah, Abu, 2006. Kekerasan Terhadap, Anak: Fenomena Masalah Sosial Kritis di Indonesia. Bandung: Nuansa.

[4] Suharto, Edi. 2005. Membangun Masyarakat Memberdayakan Rakyat. Bandung : PT. Refika Aditama.

[5] Dunn, William N. 2003. Analisis Kebijakan Publik. Yogyakarta: Gadjah Mada. University Press.

[6] Dwijowijoto, Riant Nugroho. 2004. Kebijakan Publik Formulasi, Implementasi dan Evaluasi. Jakarta: PT Elex Media Komputindo Kelompok Gramedia.

[7] Mahmudi, 2005. Manajemen Kinerja Sektor Publik. Yogyakarta: UPP AMP. YKPN.

[8] Subarsono, G. A. 2005. Analisis Kebijakan Publik. Yokyakarta: Pustaka Pelajar. 